\title{
HUBUNGAN KEMAMPUAN MANAJERIAL KEPALA SATUAN PAUD DAN SELF-EFFICACY GURU DENGAN KINERJA GURU DI KECAMATAN BUKIT KERMAN KABUPATEN KERINCI PROPINSI JAMBI
}

\author{
Rizki Surya Amanda ${ }^{1 *}$, Yoyon Suryono ${ }^{1}$ \\ 1Universitas Negeri Yogyakarta \\ 1Jl. Colombo No. 1, Depok, Sleman 55281, Yogyakarta, Indonesia \\ * Corresponding Author. Email: Rizki.surya16@student.uny.ac.id
}

\begin{abstract}
Abstrak
Penelitian ini bertujuan untuk mengukur hubungan kemampuan manajerial kepala satuan PAUD dan self-efficacy guru dengan kinerja guru PAUD. Penelitian ini merupakan penelitian korelasional dengan pendekatan kuantitatif. Sampel penelitian adalah seluruh guru PAUD non-formal yang ada di Kecamatan Bukit Kerman yang berjumlah 59 guru. Teknik sampling yang digunakan adalah sampling jenuh dimana populasi dijadikan sampel. Data dikumpulkan menggunakan angket yang telah divalidasi oleh ahli dan selanjutnya di uji validitas dan reliabilitasnya. Data dianalisis menggunakan statistik deskriptif, regresi linear sederhana dan regresi linier ganda. Hasil pengujian menunjukkan bahwa (1) terdapat hubungan yang signifikan antara kemampuan manajerial satuan PAUD dengan kinerja guru, (2) terdapat hubungan yang signifikan antara self-efficacy dengan kinerja guru, (3) terdapat hubungan yang signifikan antara kemampuan manajerial kepala satuan PAUD dan self-efficacy guru secara simultan terhadap kinerja guru.
\end{abstract}

Kata Kunci: Kemampuan manajerial, self-efficacy, kinerja guru

\section{THE RELATIONSHIP BETWEEN THE PRINCIPAL'S MANAGERIAL ABILITY AND TEACHER SELF-EFFICACY ON TEACHER'S PERFORMANCE OF EARLY CHILDHOOD EDUCATION IN BUKIT KERMAN DISTRICT KERINCI REGENCY}

\begin{abstract}
This study aims to determine the relationship between the managerial ability of the principal of early childhood education and teacher self-efficacy and teacher's performance. This study uses a quantitative approach. The sample of the research was all non-formal early childhood teachers in Bukit Kerman district, which amounted to 59 teachers. The sampling technique used was saturated sampling where the population was sampled. Data were collected using questionnaires that have been validated by experts and subsequently tested for validity and reliability. Data were analyzed using descriptive statistics, simple linear regression and multiple linear regression and coefficient of determination calculation. The result of the test shows that: (1) there is a significant relationship between the managerial ability of principal of early childhood education and teacher's performance, (2) there is a significant relationship between self-efficacy with teacher's performance, and (3) there is a significant relationship between managerial ability of principal of early childhood education and teacher self-efficacy simultaneously on teacher performance
\end{abstract}

Keywords: Managerial ability, self-efficacy, teacher performance

Permalink/DOI: http://dx.doi.org/10.21831/amp.v6i2.20335 


\section{Pendahuluan}

Pemerintah Indonesia sedang mempersiapkan generasi emas sebagai hadiah ulang tahun kemerdekaan yang ke 100. Generasi emas adalah generasi pemegang estafet kepemimpinan yang nantinya akan membangun Indonesia menjadi negara yang mandiri, makmur secara ekonomi dan berkarakter. Generasi emas seyogyanya adalah generasi yang berharga dan bernilai sehingga harus dikelola dengan baik.

Berbicara mengenai generasi emas tentunya tidak lepas dari peran pendidikan. Pendidikan adalah tempat dimana sumber daya manusia dikelola, dididik dan dibina. Jika sistem pendidikan berkualitas maka akan menghasilkan output yang berkualitas pula. Pemerintah gencar melakukan perbaikan dan pemerataan pendidikan untuk menyonsong generasi emas 2045. Salah satunya adalah perbaikan dan pemerataan dibidang Pendidikan Anak Usia Dini (PAUD). Anak-anak yang berada pada lembaga PAUD nantinya akan menjadi kader generasi emas sebagai hadiah ulang tahun satu abad kemerdekaan Indonesia.

Pendidikan anak usia dini merupakan pembinaan yang ditujukan kepada anak usia 0-6 tahun yang dilakukan melalui pemberian rangsangan pendidikan untuk membantu pertumbuhan dan perkembangan jasmani maupun rohani agar anak memiliki kesiapan dalam memasuki pendidikan lebih lanjut seperti yang dijelaskan dalam Undang-undang Nomor 20 Tahun 2003 tentang Sistem Pendidikan Nasional (Depdiknas, 2003). Kelompok anak usia 0-6 tahun akan berusia 28-34 tahun pada tahun 2045 . Usia tersebut merupakan usia produktif untuk menopang kekuatan ekonomi dan daya saing bangsa. Oleh karena itu PAUD menjadi salah satu fokus utama pemerintah dalam melahirkan generasi emas. Selain itu anak-anak usia dini juga belum terkontaminasi dengan budaya negatif sehingga perlu diarahkan dan dibina dengan memberikan layanan yang tepat agar pertumbuhan dan perkembangannya berkembang ke arah yang lebih baik.

Penyelenggaraan pendidikan anak usia dini dilakukan dalam bentuk formal, non-formal dan/atau Informal. Pendidikan jalur formal berbentuk Taman Kanak-Kanak (TK) dan Raudatul Athfal (RA), sedangkan pendidikan non-formal dilakukan melalui Kelompok bermain (KB), Taman Penitipan Anak (TPA) dan bentuk lain yang sederajat. Pendidikan anak usia dini pada jalur informal diselenggarakan dalam bentuk pendidikan keluarga atau pendidikan yang diselenggarakan oleh lingkungan (Depdiknas, 2003). Berdasarkan Data Pokok Pendidikan Anak Usia Dini dan Pendidikan Masyarakat (DAPO PAUD DIKMAS) terdapat 195.174 lembaga pendidikan anak usia dini baik formal maupun non-formal yang melayani 5.028.323 anak di seluruh wilayah Indonesia. Jumlah ini akan terus mengalami peningkatan dari tahun ke tahun. Banyaknya jumlah lembaga mencerminkan ketertarikan dan kesadaran masyarakat akan pentingnya pelaksanaan PAUD di Indonesia.

Peningkatan jumlah lembaga PAUD tentunya harus dibarengi dengan manajemen yang baik pula. Tata kelola lembaga pendidikan harus dilakukan sesuai dengan standar yang telah ditetapkan. Pemerintah mengeluarkan Peraturan Menteri Pendidikan dan Kebudayaan Republik Indonesia Nomor 137 Tahun 2014 (Menteri Pendidikan dan Kebudayaan Republik Indonesia, 2014) sebagai standar nasional pengelolaan PAUD yaitu terdiri dari; (1) Standar Tingkat Pencapaian Perkembangan Anak; (2) Standar Isi; (3) Standar Proses; (4) Standar Penilaian; (5) Standar Pendidik dan Tenaga Kependidikan; (6) Standar Sarana dan Prasarana; (7) Standar pengelolaan; dan 8) Standar Pembiayaan. Setiap lembaga PAUD berkewajiban memenuhi standar tersebut agar penyelenggaraan dapat berjalan dengan efektif dan efisien. Pada penyelenggaraan tidak semua lembaga PAUD dapat memenuhi standar nasional yang telah ditetapkan, sehingga mempengaruhi kualitas pelayanan PAUD itu sendiri.

Kepala lembaga PAUD berperan dalam menentukan kesuksesan tercapainya standar pengelolaan nasional. Pengetahuan dan kepiawaian kepala sekolah dalam memanage lembaga yang dipimpinnya diperlukan dalam menerapkan standar pengelola- 
an PAUD. Stronge, Richard, \& Catano (2013, p. 163) menyebutkan beberapa karakteristik spesifik dari perilaku dan tanggung jawab kepala sekolah yang berkontribusi secara langsung terhadap aktivitas kepemimpinan terdapat dalam beberapa kategori yaitu: kepemimpinan, pengajaran, iklim sekolah, administrasi sumber daya manusia, evaluasi guru, manajemen organisasional, komunikasi dan hubungan komunitas, profesionalis kepala sekolah, serta peran kepala sekolah dalam pencapaian peserta didik.

Manajemen yang efektif merupakan salah satu faktor tercapainya penerapan pengelolaan yang baik. Manajemen adalah proses merencanakan, mengorganisasikan, memimpin dan mengendalikan usaha-usaha anggota-anggota organisasi serta pendayagunaan seluruh sumberdaya organisasi untuk mencapai tujuan yang telah ditetapkan (Wahjosumidjo, 2010, p. 94). Dalam pendidikan anak usia dini perencanaan meliputi pembuatan visi dan misi lembaga, rencana program tahunan dan rencana program semester, dan rencana evaluasi belajar. Pengorganisasian terkait dengan pengelompokan sumberdaya sesuai bidang seperti pengorganisasian guru dan pengelompokkan anak. Sedangkan fungsi kepemimpinan terkait dengan gaya pendekatan kepala sekolah dalam mempengaruhi dan memotivasi bawahannya. Evaluasi bertujuan untuk merefleksikan hasil pelaksanaan program yang diterapkan.

Kepala satuan PAUD diharapkan dapat menguasai kemampuan manajerial sehingga penyelenggaran dapat berjalan sesuai dengan standar yang telah ditetapkan. Pernyataan ini dikuatkan oleh pendapat Basri (2014, p. 172) yang menyatakan jika seluruh kompetensi manajerial dikuasai dan dilaksanakan dengan baik, maka sekolah unggul dan mandiri akan dapat dicapai. Kepala PAUD dituntut untuk dapat berimprovisasi dengan mengeluarkan ideide positif sehingga lembaga tidak bergantung pada sumber daya yang ada.

Sebagai sumber daya manusia di sekolah, kepala sekolah yang bertugas menggerakkan dan mengembangkan lembaga seharusnya dapat meningkatkan mutu seko- lah dengan menunjukkan kemampuan pengelolaan dan kemampuan dibidang manajemen. Akan tetapi banyak ditemukan pengelolaan lembaga satuan PAUD yang belum maksimal. Berdasarkan observasi yang dilakukan di dua lembaga PAUD di Kecamatan Bukit Kerman Kabupaten Kerinci, terdapat lembaga yang penyelenggaraannya tidak sesuai dengan standar nasional PAUD. Idealnya sebuah lembaga PAUD seharusnya mempunyai perencanaan yang matang baik rencana pendek maupun jangka panjang. Akan tetapi terdapat lembaga PAUD yang tidak memiliki perencanaan tersebut. Masalah lain yang ditemukan adalah perawatan sarana prasarana yang buruk seperti peralatan permainan outdoor yang sudah rusak sehingga anak-anak tidak dapat menggunakannya. Kepala sekolah tidak memiliki inisiatif untuk melakukan perbaikan terhadap sarana dan prasarana yang ada. Padahal pada prinsipnya anak usia dini harus belajar dengan nyaman dan aman tanpa ada hal-hal yang membahayakan. Penerapan manajemen yang kurang baik dapat menghambat pencapaian anak. Nzoka \& Orodho (2014, p. 86) dalam penelitiannya menegaskan bahwa the expected improved students' academic performance was not realized due largely to the fact that most school managers had not good management skill. Hal ini berarti prestasi akademis siswa yang diharapkan meningkat tidak terwujud karena sebagian besar manajer sekolah tidak memiliki kemampuan manajerial yang baik. Menurut Schermerhon (2011, p. 17) kemampuan manajerial adalah kemampuan atau karakteristik personal yang membantu tercapainya kinerja yang tinggi dalam tugas manajemen. Me-manage atau mengelola sekolah adalah mengatur agar seluruh potensi sekolah berfungsi secara optimal dalam mendukung tercapainya tujuan sekolah. Kepala sekolah mengatur agar guru dan staf lain bekerja secara optimal, dengan mendayagunakan sarana/prasarana yang dimiliki serta potensi masyarakat demi mendukung ketercapaian tujuan sekolah. Rendahnya kemampuan manajerial kepala sekolah juga mempengaruhi mutu sekolah. Hal ini senada dengan hasil penelitian yang dilaku- 
kan oleh Mukherjee, (2013, p.81) yang mengungkapkan bahwa terdapat hubungan yang kuat antara kemampuan manajerial kepala sekolah dengan peforma sekolah. Mutu sekolah dapat dilihat dari kualitas pendidik, peserta didik, proses pembelajaran, sarana prasarana serta manajemen sekolah.

Salah satu kunci utama yang paling krusial dalam meningkatkan mutu sekolah adalah guru, kerena guru merupakan pilar utama pencapaian tujuan pendidikan. Mempertimbangkan pentingnya sumber daya manusia dalam suatu organisasi, para guru adalah faktor yang paling penting dalam sistem pendidikan (Shahmohammadi, 2017, p.60). Kepala sekolah ikut berperan dalam peningkatan kinerja guru, mulai dari perekrutan hingga evaluasi. Kinerja guru dalam pembelajaran berkaitan dengan kemampuan guru dalam merencanakan, melaksanakan dan menilai pembelajaran baik proses maupun hasil pembelajaran tersebut (Mulyasa, 2013). Guru seharusnya mampu menguasai materi pembelajaran, menciptakan pembelajaran yang menyenangkan, membuat media pembelajaran yang kreatif dan inovatif, membuat penilaian dan mengevaluasi hasil pembelajaran serta mampu membuat tindak lanjut dari hasil evaluasi tersebut. Kinerja guru guru juga dapat dikaitkan dengan penguasaan kompetensi yang harus dimiliki guru yaitu kompetensi pedagogik, kompetensi profesional, kompetensi kepribadian dan kompetensi sosial.

Kompetensi guru di Indonesia masih tergolong belum maksimal. Hasil rerata ujian kompetensi guru (UKG) nasional pada tahun 2015 yaitu 56.9, sementara itu hasil UKG guru taman kanak-kanak di Kabupaten Kerinci tahun 2015 menunjukkan rerata 52,41 (Kementerian Pendidikan dan Kebudayaan). Hasil ini belum mencapai target nasional yaitu nilai rerata 55. Hasil UKG adalah cerminan pengetahuan kemampuan guru mengenai kompetensi pedagogik dan kompetensi profesional. Hal ini dapat menjadi salah satu bukti kurang maksimalnya kinerja guru sebagai pendidik. Kurangnya kompetensi dan kinerja guru berakibat pada prestasi siswa ; Sule,
2013, p. 39; Kimani, Kara, \& Njagi, 2013, p. 2)

Sejalan dengan hal di atas, lanjutan hasil observasi dan wawancara yang dilakukan terhadap guru, terdapat guru yang belum maksimal dalam mengajar. Guru cenderung pasif dalam mengelola suasana kelas. Guru memberikan kegiatan berulang yaitu mewarnai dan mengerjakan lembar kerja sehingga anak merasa bosan dan tidak tenang. Masalah lain yaitu terdapat guru yang tidak memiliki rencana pelaksanaan pembelajaran harian (RPPH). Perangkat ini merupakan perangkat penting dalam melaksanakan pembelajaran. Kegiatan pembelajaran pada pendidikan anak usia dini seharusnya berdasar pada RPPH yang telah dibuat sebelumnya yang mencakup tema, kegiatan dan media pembelajaran. Pada proses pembelajaran guru hanya menggunakan media yang tersedia seperti papan tulis, buku tulis dan lembar kerja. Permasalahan-permasalahan diatas menggambarkan belum maksimalnya kinerja guru. Peran guru seharusnya terus ditingkatkan karena mereka adalah pilar utama di sektor ini (Johari, Yean Tan, \& Tjik Zulkarnain, 2018, p. 108).

Ada banyak faktor yang mempengaruhi kinerja guru. Salah satunya adalah selfefficacy. Self-efficacy adalah keyakinan diri seseorang bahwa ia dapat menguasai situasi dan memberi hasil positif atas apa yang telah dikerjakan. Bandura (1997, p. 5) mengatakan Self-efficacy adalah penilaian diri, apakah seseorang dapat melakukan tindakan yang baik atau buruk, tepat atau salah, bisa atau tidak bisa mengerjakan sesuai dengan yang dipersyaratkan. Self-efficacy guru mempunyai dampak besar pada kualitas pembelajaran yang akan dialami anak didalam kelas. Guru dengan self efficacy yang rendah sering terperosok dalam permasalahan kelas dan cenderung mengatakan bahwa kemampuan anak yang rendah merupakan alasan mengapa mereka tidak menguasai pembelajaran (Santrock, 2011, p. 450). Hasil penelitian Türkoğlu, Cansoy, \& Parlar (2017, p. 769) membuktikan bahwa keyakinan self-efficacy guru prasekolah adalah indikator signifikan dari kepuasan 
profesional guru dan variabel profesional yang berkaitan dengan keyakinan guru prasekolah memiliki pengaruh pada keterlibatan siswa, strategi pengajaran dan keterampilan manajemen kelas. Sak (2015, p.1629) mengatakan penting untuk memahami bagaimana self-efficacy guru dapat mempengaruhi proses belajar siswa.

\section{Metode Penelitian}

Penelitian ini menggunakan penelitian korelasional dengan pendekatan kuantitatif. Penelitian ini dilaksanakan di 16 lembaga PAUD yang tersebar di Kecamatan Bukit Kerman Kabupaten Kerinci Propinsi Jambi dengan jumlah 59 guru. Teknik sampling yang digunakan adalah sampling jenuh, artinya populasi dijadikan sampel. Teknik pengumpulan data yang digunakan adalah angket. Angket berisi pernyataan dari masing-masing variabel yaitu kemampuan manajerial kepala satuan PAUD, selfefficacy guru dan kinerja guru. Penskoran angket kemampuan manajerial kepala satuan PAUD dan kinerja guru menggunakan rating scale. Rating scale pada penelitian ini mempunyai empat pilihan jawaban berupa skor yaitu skor 4 berarti sangat baik, skor 3 berarti baik, skor 2 berarti cukup, dan skor 1 berarti kurang. Skala pengukuran yang digunakan untuk mengukur self-efficacy guru adalah skala Likert yang terdiri dari empat pilihan jawaban yaitu: sangat setuju (SS), setuju (S), kurang setuju (KS), dan sangat tidak setuju (STS). Butir dalam skala self-efficacy guru terdiri dari item favorable (item F) dan item unfavorable (item UF). Item favorable adalah item yang berisi pernyataan positif sedangkan item unfavorable adalah item yang berisi pernyataan negatif. Adapun indikator kemampuan manajerial kepala satuan PAUD adalah perencanaa, pengorganisasian, penggerakkan, pengawasan, evaluasi dan pelaporan. Indikator self-efficacy guru adalah instructional strategies, student engagement dan classroom Management. Indikator kinerja guru yaitu merencanakan pembelajaran, melaksanakan pembelajaran, dan menilai pembelajaran. Pengujian validitas menggunakan menggunakan validitas konstrak (construct validity). Validitas konstrak menggunakan pendapat para ahli (judgment experts). Setelah intrumen disetujui oleh para ahli maka dilanjutkan dengan dengan uji coba instrumen. Instumen diuji cobakan pada guru PAUD (KB, TPA, dan SPS) di beberapa kecamatan di Kabupaten Kerinci yang berjumlah 30 orang guru.

Hasil perhitungan angket yang telah diujicobakan dibandingkan dengan angka kritik pada tabel product moment atau $r_{\text {tabel }}$

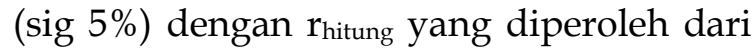
pengujian menggunakan spss for window ver 17.0 Hasil uji coba angket kinerja guru didapatkan 31 item valid dan 4 item tidak tidak valid. Pada hasil uji coba instrumen kemampuan manajerial kepala PAUD didapatkan jumlah item yang valid sebanyak 25 item dan item yang gugur sebanyak 3 item Hasil uji coba instrumen self-efficacy terdapat 22 item yang valid sedangkan jumlah item yang gugur sebanyak 2 item. Dengan demikian, setelah menggugurkan item yang tidak valid maka jumlah item yang digunakan angket kinerja guru berjumlah 31 item, kemampuan manajerial kepala satuan PAUD sebanyak 25 item untuk variabel dan self-efficacy guru sebanyak 22 item.

Pengujian reliabilitas dalam penelitian ini menggunakan internal consistency yaitu dilakukan dengan cara menguji cobakan intrumen sekali saja, kemudian data yang diperoleh dianalisis dengan teknik tertentu. Pengujian ini dilakukan dengan program spss for window ver 17.0 menggunakan Alpha Cronbach's yaitu dengan membandingkan nilai koefisien alpha. Suatu instrumen dapat dikatakan memiliki reliabilitas yang tinggi jika nilai koefisien alpha Cronbach lebih besar dari 0,70.

Hasil reliabilitas angket kemampuan manajerial kepala satuan PAUD yaitu 0,905, self-efficacy guru yaitu 0,861, dan kinerja guru yaitu 0,882 . Dengan hasil uji reliabilitas tersebut maka dapat dikatakan bahwa ketiga angket yakni kinerja guru, kemampuan manajerial kepala satuan PAUD, dan selfefficacy guru adalah reliabel. Dengan demikian, ketiga angket tersebut layak digunakan untuk mengambil data penelitian. 
Adapun teknik analisis data dalam penelitian ini menggunakan teknik analisis deskriptif, analisis regresi sederhana dan analisis regresi ganda. Analisis deskriptif digunakan untuk mendeskripsikan atau menggambarkan keadaan subyek penelitian tanpa melakukan pengambilan kesimpulan. Skor jawaban masing-masing responden akan dikategorikan menjadi tiga kategori yaitu tinggi, sedang, dan rendah. Analisis data dalam penelitian ini menggunakan analisis regresi. Analisis regresi dalam penelitian ini menggunakan uji linearitas dan uji multikoliniaritas. Uji linieritas bertujuan untuk mengetahui apakah dua varabel mempunyai hubungan yang linear atau tidak secara signifikan. Uji multikolinearitas bertujuan untuk menguji atau membuktikan ada atau tidaknya hubungan yang linear antara variabel kemampuan manajerial kepala satuan PAUD (X1) dan self-efficacy guru (X2).

Salah satu syarat regresi adalah dua variabel independen tidak berhubungan satu sama lain. Uji regresi linier sederhana digunakan untuk menguji hipotesis 1 dan 2 yang berbunyi "ada hubungan yang signifikan antara kemampuan manajerial kepala satuan PAUD dengan kinerja guru" dan "ada hubungan yang signifikan antara selfefficacy guru dengan kinerja guru". Uji regresi ganda digunakan untuk menguji hipotesis ke 3 yaitu "ada hubungan yang signifikan kemampuan manajerial kepala satuan PAUD dan self-efficacy guru dengan kinerja guru".

\section{Hasil Penelitian dan Pembahasan}

Data hasil penelitian kemudian dideskripsikan dan dikategorikan. Berikut adalah kategori skor setiap variabel.

Tabel 1. Kategori Skor Kinerja Guru

\begin{tabular}{cccc}
\hline Kategori & Skor & $\mathrm{F}$ & $\%$ \\
\hline Tinggi & $X>93,2$ & 13 & $22 \%$ \\
Sedang & $76,4<X<93,2$ & 36 & $61 \%$ \\
Rendah & $X<76,4$ & 10 & $17 \%$ \\
\hline
\end{tabular}

Tabel 2. Kategori Skor Kemampuan Manajerial Kepala satuan PAUD

\begin{tabular}{cccc}
\hline Kategori & Skor & $\mathrm{F}$ & $\%$ \\
\hline Tinggi & $\mathrm{X}>75,6$ & 12 & $20,3 \%$ \\
Sedang & $63,3<\mathrm{X}<75,6$ & 36 & $61 \%$ \\
Rendah & $\mathrm{X}<63,3$ & 11 & $18,7 \%$ \\
\hline
\end{tabular}

Tabel 3. Kategori Skor Self-Efficacy Guru

\begin{tabular}{cccc}
\hline Kategori & Skor & $\mathrm{F}$ & $\%$ \\
\hline Tinggi & $\mathrm{X}>67,9$ & 18 & $30,5 \%$ \\
Sedang & $55,9<\mathrm{X}<67,9$ & 34 & $57,6 \%$ \\
Rendah & $\mathrm{X}<55,9$ & 7 & $11,9 \%$ \\
\hline
\end{tabular}

Data yang sudah diperoleh kemudian di uji terlebih dahulu dalam berbagai uji asumsi sebelum melakukan uji regresi. Uji Asumsi meliputi uji normalitas, uji linearitas, dan uji multikolinearitas. Berikut ini akan dipaparkan hasil analisis hasil uji asumsi.

Hasil uji normalitas menunjukkan nilai probabilitas (signifikansi) untuk kemampuan manajerial kepala satuan PAUD sebesar $0,181(\mathrm{p}>0,05)$, self-efficacy guru sebesar $0,060(p>0,05)$, dan kinerja guru sebesar $0,153$ ( $\mathrm{p}>0,05)$. Melihat nilai probabilitas ketiga variabel penelitian lebih besar dari 0,05 maka dapat disimpulkan seluruh data variabel penelitian terdistribusi normal.

Dua variabel dikatakan mempunyai hubungan yang linear apabila signifikansinya kurang dari 0,05 maka model regresi linear diterima (Sudjana, 2002,p.128). Hasil output spps menunjukkan bahwa kemampuan manajerial kepala PAUD dengan kinerja guru memiliki hubungan yang linear dengan $p=0,000$ dan self-efficacy guru memiliki hubungan yang linear dengan $p=0,000$. Dengan demikian, dapat disimpulkan bahwa variabel-variabel bebas memiliki hubungan yang linear dengan variabel terikat.

Pada uji multikolinieritas didapatkan hasil output spss diatas nilai tolerance yaitu 0,508 dan VIF 1,967. Dengan perolehan di atas dapat disimpulkan bahwa nilai tolerance lebih besar dari $0,1(0,508>0,1)$ dan nilai VIF lebih kecil dari $10(1,967<10)$ maka tidak terjadi multikolinearitas.

Hasil pengujian Hipotesis pertama didapatkan bahwa terdapat hubungan yang 
signifikan antara kemampuan manajerial kepala satuan PAUD denga kinerja guru PAUD di Kecamatan Bukit Kerman. Hasil pengujian hipotesis pertama dapat dilihat pada Tabel 4 .

Tabel 4. Hasil Uji Hipotesis 1

\begin{tabular}{llccc}
\hline \multicolumn{1}{c}{ Sumber } & Koef Reg & $\mathrm{R}$ & $\mathrm{R}^{2}$ & $\mathrm{P}$ \\
\hline Konstanta & 15.631 & 0,727 & 0,529 & 0,000 \\
$\mathrm{X} 1$ & 0,996 & & & \\
\hline
\end{tabular}

Data pada Tabel 4 menunjukkan bahwa nilai probabilitas kurang dari 0,05. Dengan demikian dapat dinyatakan bahwa terdapat hubungan yang positif dan signifikan anatara kemampuan manajerial kepala satuan PAUD dengan kinerja guru. Hasil uji regresi untuk hipotesis 1 didapatkan nilai konstanta (a) yaitu 15,631 dan nilai koefisien regresi (b) sebesar 0,996, sehingga dapat dibuat persamaan regresi linier sederhana yaitu $\mathrm{Y}=15,631+0,996 \mathrm{X}_{1}$. Persamaan di atas mennggambarkan bahwa nilai koefisien X1 bernilai positif sebesar 0,996 yang berarti jika kemampuan manajerial kepala PAUD meningkat 1 poin maka nilai kinerja guru akan meningkat 0,996 poin. Perolehan nilai koefiesien korelasi sebesar 0,727 dan koefisien determinasi sebesar 0,529. Hal ini berarti bahwa kemampuan manajerial kepala satuan PAUD secara parsial berpengaruh sebesar 52,9\% terhadap kinerja guru.

Kemampuan manajerial adalah kemampuan kemampuan seseorang dalam melaksanakan fungsi-fungsi manajemen untuk mencapai tujuan organisasi. Hasil temuan memperlihatkan bahwa kemampuan manajerial kepala satuan PAUD di Kecamatan Bukit Kerman berada pada kategori sedang. Hasil ini berarti guru memberikan persepsi yang cukup baik terhadap kemampuan manajerial kepala sekolah.

Hasil temuan menunjukkan bahwa kemampuan manajerial kepala satuan PAUD mempunyai hubungan yang positif dan signifikan dengan kinerja guru. Semakin baik kemampuan manajerial kepala satuan PAUD maka kinerja guru juga akan semakin baik. Kemampuan manajerial kepala satuan PAUD memberikan kontribusi sebesar $52,9 \%$ dan sisanya dipengaruhi oleh va- riabel lain. Keterkaitan antara kemampuan manajerial kepala sekolah dijelaskan oleh Gorton (1976, p. 207) yang menyatakan bahwa kompetensi manajerial kepala sekolah mengambil peran penting dalam meningkatkan kinerja guru. Mulyasa (2013, p. 227) menambahkan faktor yang mempengaruhi kinerja guru yaitu manajemen atau gaya kepemimpinan kepala sekolah, sistem manajemen yang diterapkan oleh kepala sekolah dalam mengelola dan memimpin serta mengendalikan tenaga pendidikan. Tehseen \& Hadi (2015, p. 241) juga mengatakan faktor yang dapat mempengaruhi kinerja guru berdasarkan analisis literatur yaitu motivasi, karakteristik guru, karakteristik siswa, dan konteks sekolah (fasilitas, dukungan administratif, kpemimpinan kepala sekolah). Oleh karena itu kepala sekolah harus bertindak sebagai manajer yang efektif. Manajer yang efektif yaitu manajer yang menjalankan semua fungsi manajemen dengan tepat, efektif dan efisien. Kepala sekolah seharusnya dapat mengembangkan semua sumber daya organisasi terutama guru sebagai tonggak mutu sekolah. Kepala sekolah baik dapat menelola lingkungan organisasi yang nyaman agar guru dapat bekerja dengan maksimal. Hal yang sama diungkapkan oleh $\mathrm{Xu} \&$ Ye (2014, p. 1283) yang mengatakan atmosfer organisasi memainkan peran dalam kompetensi dan kinerja pekerjaan. Penelitian sebelumnya yang dilakukan oleh Elfaradis (2016) juga mendukung adanya hubungan antara kemampuan manajerial kepala sekolah dengan kinerja guru dimana. Kepala sekolah dan guru sejatinya dapat bekerja sama dengan baik dan melakukan tugasnya masingmasing dengan baik.

Hasil pengujian Hipotesis kedua didapatkan bahwa terdapat hubungan yang signifikan antara self-efficacy guru dengan kinerja guru PAUD di Kecamatan Bukit Kerman. Hasil pengujian hipotesis kedua dapat dilihat pada Tabel 5.

Tabel 5. Hasil uji hipotesis 2

\begin{tabular}{llccc}
\hline Sumber & Koef Reg & R & R2 & P \\
\hline Konstanta & 5,830 & 0,914 & 0,835 & 0,000 \\
X2 & 1,275 & & & \\
\hline
\end{tabular}


Data pada tabel 5 menunjukkan bahwa nilai probabilitas kurang dari 0,05. Dengan demikian dapat dinyatakan bahwa terdapat hubungan yang signifikan antara self-efficacy guru PAUD dan kinerja guru. Berdasarkan hasil uji regresi didapatkan nilai konstanta (a) yaitu 5,830 dan nilai koefisien regresi (b) sebesar 1,275, sehingga dapat dibuat persamaan regresi linier sederhana yaitu $Y=5,830+1,275 X_{1}$.

Persamaan diatas mennggambarkan bahwa nilai koefisien self-efficacy guru bernilai positif 1,275 yang berarti jika selfefficacy guru PAUD meningkat 1 poin maka nilai kinerja guru akan meningkat 1,275 poin. Perolehan nilai koefiesien korelasi sebesar 0,914 dan koefisien determinasi sebesar 0,835 . Hal ini berarti bahwa kemampuan self-efficacy guru PAUD secara individual berpengaruh sebesar $83,5 \%$ terhadap kinerja guru.

Self-efficacy guru merupakan salah satu faktor internal yang mempengaruhi kinerja guru. Self-efficacy guru PAUD di Kecamatan Bukit Kerman berada pada kategori sedang. Hal ini berarti guru cukup yakin terhadap kemampuannya sebagai guru.

Hasil uji hipotesis menunjukkan bahwa self-efficacy guru PAUD memiliki hubungan yang positif dan signifikan terhadap kinerja guru. Self-efficacy guru memberikan kontribusi sebesar $83,5 \%$ terhadap kinerja guru secara individual. Hasil ini menunjukkan bahwa self-efficacy guru memberikan pengaruh yang sangat besar pada kinerja guru. Semakin tinggri self-efficacy guru makan semakin tinggi pula kinerjanya. Besarnya pengeruh self-efficacy terhadap kinerja guru membuktikan bahwa faktor internal ternyata lebih kuat dalam mempengaruhi kinerja seseorang. Seseorang akan bekerja dengan optimal jika memiliki dorongan yang kuat dari dalam dirinya. Chang \& Engelhard (2016, p. 177) menyatakan beberapa penelitian telah menunjukkan bahwa self-efficacy yang kuat terkait dengan antusiasme, motivasi yang lebih tinggi, usaha yang lebih besar, ketekunan, dan ketahanan di seluruh rentang karir mengajar. Hal ini menunjukkan bahwa self-efficacy guru, keyakinan yang dipegang oleh guru mengenai kompetensi profesional mereka sendiri dapat mempengaruhi profesional mereka.

Besarnya pengaruh self-efficacy guru pada kinerja guru PAUD didukung oleh beberapa penelitian. Temuan penelitian tersebut menyatakan guru akan mempunyai kinerja yang baik bila mempunyai selfefficacy yang tinggi (Olayiwola, 2011, p. 441; Toran 2017, p.121). Keyakinan guru dalam pengajaran membantu untuk menentukan kinerja profesional mereka.

Tabel 6. Hasil uji hipotesis III

\begin{tabular}{lllll}
\hline Sumber & Koef Reg & $\mathrm{R}$ & $\mathrm{R}^{2}$ & $\mathrm{P}$ \\
\hline Konstanta & $-0,032$ & 0,922 & 0,850 & 0,000 \\
X1 & 0,232 & & & \\
X2 & 1,109 & & & \\
\hline
\end{tabular}

Analisis terhadap variabel kinerja guru berada pada kategori sedang. Hasil ini menunjukkan bahwa guru PAUD di Kecamatan Bukit Kerman mempunyai kinerja yang cukup baik. Hasil uji hipotesis menunjukkan bahwa kemampuan manajerial kepala satuan PAUD dan self-efficacy guru berpengaruh positif dan signifikan terhadap terhadap kinerja guru. Hal ini menunjukkan pentingnya variabel kemampuan manajerial kepala satuan PAUD dan self-efficacy guru secara bersama-sama untuk meningkatkan kinerja guru. Melalui persamaan regresi berganda dapat diartikan, bahwa semakin tinggi kemampuan manajerial kepala satuan PAUD dan self-efficacy guru, maka akan semakin tinggi pula peningkatan kinerja guru. Sebaliknya, jika semakin rendah kemampuan manajerial kepala satuan PAUD dan self-efficacy guru, maka semakin rendah pula kinerja guru.

Perolehan nilai koefesien determinasi yaitu sebesar 0,850 yang berarti kemampuan manajerial kepala satuan PAUD dan self-efficacy guru berpengaruh sebesar 85\% terhadap kinerja guru secara simultan. Adapun perolehan sumbangan efektif kemampuan manajerial kepala satuan PAUD terhadap kinerja guru adalah 12,2\% sedangkan perolehan sumbangan efektif self-efficacy guru terhadap kinerja guru yaitu $72,8 \%$. Hasil ini memperlihatkan self-efficacy jauh lebih 
dominan memberikan kontribusi kepada kinerja guru. Hal ini didukung oleh penelitian Cherian \& Jacob (2013, p. 87) yang mengungkapkan bahwa self-efficacy guru prasekolah adalah prediktor kuat dalam praktik pengajaran mereka. Guru yang memiliki self-efficacy tinggi percaya bahwa mereka mampu melaksanakan tugas dengan baik dan yakin akan hasil yang positif. Khurshid, Qasmi, \& Ashraf (2012, p. 205) memandang self-efficacy guru dan kinerja pekerjaan seagai komponen yang paling penting dari sistem pendidikan dan jika guru memiliki kepercayaan diri dan selfefficacy akan membantu mereka untuk bekerja secara efektif dan efisien.

Meskipun self-efficacy guru menjadi faktor yang paling dominan, faktor kemampuan manajerial kepala satuan PAUD sebagai faktor eksternal juga berkontribusi dalam meningkatkan kinerja guru. Tehseen \& Hadi (2015, p. 233) menyatakan manajemen yang efektif membuat perbaikan signifikan dalam perilaku dan kinerja guru. Hal ini berarti kinerja guru juga akan meningkat jika dibarengi dengan manajemen sekolah yang baik. Kepala sekolah dapat melaksanakan kegiatan pengembangan kinerja guru dalam pembelajaran. Wirawan (2009) menegaskan kinerja guru merupakan hasil sinergi faktor eksternal dan internal. Dengan demikian self-efficacy yang tinggi ditambah dengan kemampuan manajerial kepala sekolah yang tinggi akan meningkatkan kinerja.

\section{Simpulan}

Berdasarkan hasil penelitian dan pembahasan, dapat disampaikan simpulan sebagai berikut. Analisis deskriptif memperlihatkan kemampuan manajerial kepala satuan PAUD, self-efficacy guru, dan kinerja guru berada pada kategori sedang. Hasil uji hipotesis menunjukkan Kemampuan manajerial kepala satuan PAUD mempunyai hubungan yang positif dan signifikan dengan kinerja guru. Kemampuan manajerial memberikan kontribusi sebesar 52,9\% terhadap kinerja guru. Dengan demikian semakin tinggi kemampuan manajerial kepala satu- an PAUD maka semakin tinggi pula kinerja guru. Self-efficacy guru mempunyai hubungan yang positif dan signifikan dengan kinerja guru. Self-efficacy guru memberikan kontribusi sebesar 83,5\% terhadap kinerja guru. Dengan semikian semakin tinggi selfefficacy guru maka kinerja guru juga semakin tinggi. Kemampuan manajerial kepala satuan PAUD dan self-efficacy guru secara bersama-sama mempunyai hubungan yang positif dan signifikan terhadap kinerja guru. Kemampuan manajerial kepala satuan PAUD dan self-efficacy guru memberikan kontribusi $85 \%$ terhadap kinerja guru. Hal ini berarti kemampuan manajerial yang baik dan self-efficacy guru yang tinggi akan dapat meningkatkan kinerja guru.

Sehubungan dengan hasil diatas perlu adanya upaya dari guru dan kepala sekolah untuk meningkatkan kinerja guru, selfefficacy dan kemampuan manajerial. Hasil penelitian juga menunjukkan bahwa selfefficacy guru merupakan faktor yang paling dominan berpengaruh terhadap kinerja guru. Oleh karena itu, self-efficacy guru dapat menjadi salah satu aspek yang sangat perlu diperhatikan dalam meningkatkan kinerja guru di Kecamatan Bukit Kerman.

\section{Daftar Pustaka}

Bandura, A. (1997). Self-efficacy, the exercise of control. New York: W.H. Freeman and Company.

Basri, H. (2014). Kepemimpinan kepala sekolah. Bandung: Pustaka Media.

Chang, M. L., \& Engelhard, G. (2016). Examining the Teachers' Sense of Efficacy Scale at the Item Level With Rasch Measurement Model. Journal of Psychoeducational Assessment, 34(2), 177-191. https:// doi.org/10.1177/07342829155 93835

Cherian, J., \& Jacob, J. (2013). Impact of Self Efficacy on Motivation and Performance of Employees. International Journal of Business and Management, 8(14), 80-88. https:// doi.org/10.5539/ijbm.v8n14p 
80

Depdiknas. Undang-Undang Nomor 20

Tahun 2003 tentang Sistem

Pendidikan Nasional (2003). Jakarta.

Elfaradis, F. (2016). Pengaruh kompetensi manajerial kepala sekolah dan motivasikerja terhadap kinerja guru di Tarbiyah Muallimin Al-Islamiyah (TMI) Putri Al-Amien Prenduan Sumenap Madura. Tesis. Unpublished. Universitas Islam Negeri Malik Maulana Ibrahim Malang.

Gorton, R. A. (1976). School administration: challenge and opportunity for leadership. USA: Brown company publisher.

Johari, J., Yean Tan, F., \& Tjik Zulkarnain, Z. I. (2018). Autonomy, workload, work-life balance and job performance among teachers. International Journal of Educational Management, 32(1), 107120. https://doi.org/10.1108/IJEM10-2016-0226

Khurshid, F., Qasmi, F. N., \& Ashraf, N. (2012). The Relationship Between Teachers' Self Efficacy and Their Perceived Job Performance. Journal of Contemporary Research in Business, 3(10), 204-223.

Kimani, G. N., Kara, A. M., \& Njagi, L. W. (2013). Teacher factors influencing students' academic achievement in secondary schools in Nyandarua County, Kenya. International Journal of Education and Research, 1(3), 1-14.

Menteri Pendidikan dan Kebudayaan Republik Indonesia. Peraturan Menteri Pendidikan dan Kebudayaan Republik Indonesia Nomor 137 Tahun 2014 tentang Standar Nasional Pendidikan Anak Usia Dini (2014).

Mukherjee, S. (203AD). A Study of the Managerial Skills of School Principals and Performance of Schools. Indian Journal of Research, 54(8), 81-86.

Mulyasa. (2013). Uji kompetensi dan penilaian kinerja guru. Bandung: Rosdakarya.
Nzoka, J. T., \& Orodho, J. A. (2014). School management and students ' academic performance: how effective are strategies being employed by school managers in secondary schools in Embu. International Journal of Humanities and Social Science, 4(9), 8699. Retrieved from http://www.ijhssnet.com/journals/V ol_4_No_9_July_2014/9.pdf

Olayiwola, I. (2011). Self-efficacy as predictor of job performance of public secondary school teachers in Osun State. IFE PsychologIA, 19(1). https:// doi.org/10.4314/ifep.v19i1.64 612

Sak, R. (2015). Comparison of self-efficacy between male and female pre-service early childhood teachers. Early Child Development and Care, 185(10), 16291640.

https:/ / doi.org/10.1080/03004430.201 5.1014353

Santrock, J. W. (2011). Psikologi pendidikan. Jakarta: Salemba Humanika.

Schermerhon, J. R. (2011). Manajemen. (P. Putranta, Trans.). Yogyakarta: Andi Offset.

Shahmohammadi, N. (2017). The Evaluation of Teachers' Job Performance Based on Total Quality Management (TQM). International Education Studies, 10(4), 58. https:// doi.org/10.5539/ies.v10n4p58

Stronge, J. H., Richard, H. B., \& Catano, N. (2013). Kualitas kepala sekolah yang efektif. (S. Mahyuni, Trans.). Jakarta Barat: PT. Indeks.

Sule, M. (2013). The influence of the principal's supervisory demonstration strategy on teachers' job performance in Nigeria secondary schools. IOSR Journal Of Humanities And Social Science, 11(1), 39-44.

Tehseen, S., \& Hadi, N. U. (2015). Factors influencing teachers' performance and retention. Mediterranean Journal of 
Social Sciences, 6(1).

https:// doi.org/10.5901/mjss.2015.v6 n1p233

Toran, M. (2017). An Analysis of Preschool Teachers' Sense of Efficacy: A Case of TRNC. Journal of Education and Training Studies, 5(4), 121.

https:// doi.org/10.11114/jets.v5i4.21 71

Türkoğlu, M. E., Cansoy, R., \& Parlar, H.

(2017). Examining relationship between teachers' self-efficacy and job satisfaction. Universal Journal of Educational Research, 5(5), 765-772. https://doi.org/10.13189/ujer.2017.05 0509
Wahjosumidjo. (2010). Kepemimpinan kepala sekolah. Jakarta: Rajawali Pers.

Wirawan. (2009). Evaluasi kinerja sumber daya manusia teori aplikasi dan penelitian. Jakarta: Salemba Empat.

Xu, A., \& Ye, L. (2014). Impacts of teachers' competency on job performance in research universities with industry characteristics: Taking academic atmosphere as moderator. Journal of Industrial Engineering and Management, 7(5), 1283-1292. https:/ / doi.org/10.3926/jiem.1261 